\title{
The impact of Musharakah financing on the monetary policy in the Islamic economy
}

\author{
Hatem Adela
}

\author{
Sadat Academy for Management Sciences, American University in the Emirates, \\ Dubai, United Arab Emirates
}

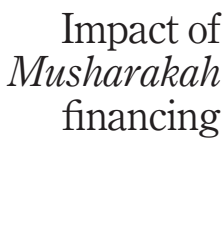

Received 27 September 2018 Accepted 27 September 2018

\begin{abstract}
Purpose - This paper aims to contribute to formulating the methodological framework for a paradigm of Islamic economics, using the development of the conventional economics, theoretical and mathematical methods.

Design/methodology/approach - The study based on the inductive and mathematical methods to contribute to economic theory within the methodological framework for Islamic Economics, by using the return rate of Musharakah rather than the interest rate in influence the economic activity and monetary policy.

Findings - Via replacement, the concept of the interest rate by the return rates of Musharakah. It concludes that the central bank can control the monetary policy, economic activity and the efficient allocation of resources by using the return rates of Musharakah through the framework of Islamic economy.

Practical/implications - The study is a contribution to formulate the methodological framework for a paradigm of Islamic economics, where it investigates the impact of return rates of Musharakah on the money market and monetary policy, by the mathematical methods used in the conventional economy. Also, the study illustrates the importance of further studies that examine the methodological framework for Islamic Economics.

Originality/value - The study aims to contribute to formulating the Islamic economic theory, through the return rate of Musharakah financing instead of the interest rate, and its effectiveness of the monetary policy. As well as reformulating the concepts of the investment function, the present value and the marginal efficiency rate of investment according to the Islamic economy approach.
\end{abstract}

Keywords Monetary policy, Inflation rate, Interest rate, Return rate of Musharakah, Present value, Marginal sufficiency rate of investment

Paper type Research paper

\section{Introduction}

There are various studies in the field of Islamic economics to get the economic theory includes all sectors in the economy, but most studies have focused on legislative and jurisprudential Islamic finance transactions in banks, as well as the economic effects of different types of Islamic finance framework. "Bosca (2015)" showed that about 50 per cent of the studies related to Islamic economics in English during the period 1994 to 2005 are

(C) Hatem Adela. Published in Review of Economics and Political Science. Published by Emerald Publishing Limited. This article is published under the Creative Commons Attribution (CC BY 4.0) licence. Anyone may reproduce, distribute, translate and create derivative works of this article (for both commercial and non-commercial purposes), subject to full attribution to the original publication and authors. The full terms of this licence may be seen at http://creativecommons.org/licences/by/4.0/ legalcode

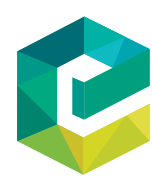

Review of Economics and Political Science . $3 / 4,2018$ pp. $139-152$ pp. 139-152
Emerald Publishing Limited
2631-356 DOI 10.1108/REPS-10-2018-014 
REPS

$3,3 / 4$

related to these two areas, while only 19 per cent focused on the methodological framework for a form of Islamic economics (Bosca, 2005).

Despite the multiplicity of Islamic modes of financing such as Murabaha, Musharakah, Mudharabah, Ijara and others, the studies of these financing methods within the model of Islamic economics are relatively few. That shows the necessity of using the conventional economics instruments to benefit from the progress in theoretical, mathematical and statistical models in the conventional economy to get more integrated drafting of the Islamic economic model.

Musharakah financing is the most vital method to influence the economic activity in the Islamic Economy; which includes Musharakah of depositors, bank and investors in the funding of project and participation in the profits and risks. Therefore, it affects savings, investment and the domestic resources gap. Comparing with the interest rate, the implementation of Musharakah financing considers more flexible than the interest rate, it includes three rates of return; a return rate of depositors' Musharakah, a return rate of bank's Musharakah and a return rate of investors' Musharakah. While, the interest rate determines arbitrarily, according to the maturities of loans between the bank and the depositor on the one hand, and between the bank and the investor, on the other hand. The investor shall bear the interest as a financing risk. Also, the mechanism of using the interest rate in the money market equilibrium includes lags to transform the savings into investments and influence the economic activity, while the Musharakah financing assures the participation of all parties simultaneously; the bank, the saver and the investor in the Musharakah process. Therefore, the lag is limited to the period of implementation of the Musharakah process.

As well as the concept of zakat influences in the affirmative on the Musharakah financing, through encouraging individuals to pump money into the economic activity cycle by Musharakah and reduce the desire to hold funds for the provision or speculation purposes.

The replacement of the interest rate by return rates of Musharakah requires reformulating the concepts of present value, the marginal efficiency rate of investment and the investment function within the Islamic Economics. That affects the control of the legal reserve ratio in commercial banks and the level of economic activity.

Accordingly, the research was divided into six sections. As discussed below, Section 3 investigates the significance of the contemporary Islamic Banking. Section 4 investigates the literature review of Musharakah financing. Section 5 studies the impact on investment by the return rate of Musharakah. Section 6 examines the present value and the return rate of Musharakah. Section 7 analyzes the marginal sufficiency rate of investment and the return rate of Investor's Musharakah. Section 8 analyzes the monetary policy and the return rate of depositors' musharakah and Bank's musharakah.

\section{Research hypotheses}

H1. The inflation within a framework of the Islamic economy can be used as the discount rate, as well as to calculate the present value.

H2. The return rates of musharakah can be used as an alternative of the interest rate to affect the economic activity.

H3. The central bank can use the return rates of musharakah as an instrument to affect the economic activity. 


\subsection{The significance of the contemporary Islamic Banking}

A unique feature that differentiates Islamic banking from conventional banking, in theory, is its profit-and-loss sharing (PLS) paradigm. Where banks are not allowed to offer a fixed rate of return on deposits and are not allowed charging interest on loans (Iqbal, 1997). Under the PLS paradigm, the ex ante fixed rate of return in financial contracting is replaced with a rate of return that is uncertain and determined ex post on a profit-sharing basis. Only the profit-sharing ratio between the capital provider and the entrepreneur is determined ex ante. PLS contracts, in general, allow two or more parties to pool their resources for investment purposes and to share the investment's profit-and-loss (Chong and Liu, 2009).

Many conventional banks are now offering products that aimed at non-Muslims through Islamic financing windows. The USA has developed a Dow Jones Islamic Market Index which has listed 1937 companies eligible for investment as of 2006 (Tahmina, 2013). There are now over 280 of institutions in over 60 countries. The Islamic finance industry has a recorded growth rate of over 15-20 per cent per annual (Malik et al., 2011).

In Iran, Pakistan and Sudan, only Islamic banking is allowed. In other countries, such as Bangladesh, Egypt, Indonesia, Jordan and Malaysia, Islamic banking co-exists with conventional banking. Moreover, Islamic banking is not limited to Islamic countries. In August 2004, the Islamic Bank of Britain became the first bank licensed by a non-Muslim country to engage in Islamic banking. The HSBC, University Bank in Ann Arbor and Devon Bank in Chicago offer Islamic banking products in the USA (Chong and Liu, 2009). As a result of the remarkable success achieved by Islamic banks, some conventional commercial banks proceeded to establish Islamic branches of Islamic transactions.

The Islamic banks reached 176 in 1997, with total capital of up to US\$3.7bn, and total deposits up to US $\$ 112.6 \mathrm{bn}$ by the end of 2001. The number was about 200 Islamic financial institution banks distributed across more than 40 countries and spread across the five continents of the world. With a total capital of up to US\$148bn, as the funds amounted to \$300bn and over 300 Islamic financial institutions worldwide across 75 countries holding a paid-up capital of over US\$13bn in 2007. As well as controlling assets worth US\$300-500 and investments US\$500-800bn (Khan and Bhatti, 2008). The World's 100 most significant Islamic banks have set an annual asset growth rate of 26.7 per cent. And the global Islamic Finance industry is experiencing the average growth of 15-20 per cent annually (Bank Negara Malaysia, 2007). The assets of the Islamic banking excess USD 1 trillion in 2015, it becomes one of the fastest growing economic sectors around the world and includes more than 400 Foundation manages more than US $\$ 1$ tn around the world (Ernst and Young, 2016).

Malaysia is the most developed Islamic banking market in the world; it built a successful domestic Islamic financial industry supported by a corroborative environment, comprehensive financial infrastructure, diversity of innovative Islamic instruments and maturity of the financial system, in addition to adopting global regulations and legal best practices.

Therefore, Malaysia's Islamic banking assets increased from US\$65.6bn in 2007 to US \$274.6bn in 2015 (Bank Negara Malaysia, 2007), with an average growth rate of 18-20 per cent annually (Bank Negara Malaysia, 2015). These regulations have encouraged foreign financial institutions to make Malaysia one of the world financial options through Islamic banking to conduct their funds. The financial transactions of Musharakah reached to 29.635m Ringgit by a ratio 7.8 per cent in 2016, while the Murabaha and Ijara have contracted to 7.2 and 30.6 per cent, respectively (Bank Negara Malaysia, 2018).

\subsection{Musharakah financing literature review}

Musharakah is a word of Arabic origin which means literally sharing. In the context of business and trade, it means a joint enterprise in which all the partners share the profit or 
REPS

$3,3 / 4$

loss of the joint venture. Musharakah defined as a form of partnership where two or more individuals combine their capital or labour, to share the profits, enjoying similar rights and liabilities, this type of business can be registered as a partnership with unlimited liability or as a company with limited liability. If the venture sounds feasible, the bank might consider sharing the finance of the venture after reviewing the entire requirements requested by the bank (Ahmed, 2008).

The two types of Musharakah-based financing are as follows:

(1) Joint venture project or partnership based on a mutual account without the establishment of a separate entity. The Musharakah financing agreement will be concluded between the Islamic financial institution and customer. The funds deposit to a mutual account in a lump sum or stages. The joint account registered under the customer's name, whereas the management of the account's transactions jointly managed by the Islamic financial institution and the customer.

(2) Equity Musharakah through the establishment of a private limited joint venture, a corporate entity will be established by the Islamic financial institution and the customer to operate a specific venture. The project's management process by both Musharakah parties to represent their interests and responsibilities towards the venture. The Islamic financial institution will disburse the Musharakah financing in one lump sum by additional paid up capital of the venture (Bank Negara Malaysia, 2010).

Kashi and Mohamad (2017) examine the technical issues underlying the implementation of the Musharakah and Mutanaqisah partnership (MMP) model by Islamic banks in Malaysia. The study uses a qualitative methodology based on interviews. It concludes that the MMP model is converging with the Bay' Bithaman Ajil (BBA) and conventional housing loans.

Abdullah and Saiti (2016) examine the issuance of Musharakah bonds in the structure of financing the waqf real estate development projects in Singapore in 2001 and 2002. The methodology involves a case study, including documentary and contents analysis of selected materials. The research finds the Musharakah bonds do not satisfy the conditions relating to a valid contract and lawful income.

Hassan and Soumare (2014) propose a model to study the interactions between Musharakah and Mudarabah certificate holders and the government. The model provides a unifying framework for the improvement of access to funds in the Islamic financing context. The study concludes that investors will be willing to take the risk if they believe that their capital is at least guaranteed by the government (Hassan and Soumare, 2015).

Sayim (2015) indicates the experiment of Turkish participation banks, it has four participations banks; each of them has 242 branches on an average at the end of 2013, while 32 private deposit banks have 343 branches on an average. Their profit increased by 67 per cent from 2007 to 2013 and reached to 22.5 billion TL in 2013. Also, they have some problems such as the existence of the interbank system and the guaranty insurance system.

Hassan and Smolo (2011) aim to highlight of the fundamental principles underlying implementation of Musharakah mutanaqisah (MM) and its distinctive features when compared to other modes of finance based on an extensive literature review. The study indicates that MM has a comparative advantage for both financier and the customer when compared with conventional loans.

Ariffin et al. (2015) examine the current practice of MM principle in Malaysia, based on survey questionnaires on sixteen Islamic banks. The respondents agree that the principle of profit and loss sharing element under equity-based financing represents the true spirit of Islamic banking practices. 
Tahir (2013) investigates the institutional framework for facial and monetary policies, the study suggests that the role of the government can be revised in the light of Shariah on both economic and distributive planes; it should be reduced to achieve the economic objectives in the Islamic economy.

Ouidad (2014) analyzes the Musharakah and Mudarabah financing schemes as profit loss sharing (PLS) methods to solve asymmetric information problems. The results show that Mudarabah financing provides a powerful incentive to the entrepreneur. Also, it cannot resolve moral hazard problem.

Saad and Abdul (2013) illustrate that equity financing product, in specific, MM. The study concludes that MM is superior compared to debt financing product. Also, provide a proper practice along with the pricing of MM for Islamic microfinance institutions.

Mikail and Rani (2016) suggest that the two phases of MM; the partnership and ownership should be separated with its own underlying and supporting contracts. That helps the industry players to choose the right partnership contract for MM and keep away from possible confusion.

Khatat (2016) considers the interest rate is the anchor for both conventional and Islamic banking systems. The monetary transmission can operate from the conventional to Islamic segment of the financial system through the interest rate channel, and the Islamic bank may rely on the interest rate to price their contracts.

Ramic (2012) explains that the participation banking does not exclusive the Islamic banks; it can be run by the conventional banks under certain conditions in accordance with Shariah standards. Its opportunity to open new dimensions for the banking industry in Europe to increase competition, diverse responsibility and create new services, in addition to, attracting the savings of the European Muslims into the banking system.

Ahroum and Achchab (2017) introduce a new framework by applying the Gordon and Shapiro model on the valuation of sukuk Musharakah with a joint venture as underlying, where negotiating of the profit and loss sharing ratio is not sufficient to have a fair price of sukuk Musharakah. This framework differs from the standard bond pricing methodology broadly, which uses nowadays in the determination of sukuk prices.

Selim (2008) establishes an Islamic finance approach of Musharakah based on the conventional capital asset pricing model (CAPM), the study finds the existence of Musharakah necessarily yields a lower beta-risk of investments than that compared to the market. Also, a zero risk-free rate of return is optimal in the case of Musharakah.

Hasan (2016) proposes an alternative model of the equated monthly installment on MM to overcome the practice of Islamic banks that using the equated monthly installment (EMI) on MM. The EMI model involves compounding the return on capital and passes the ownership of the property to the partner at a slower rate than the rate of capital amortization until the contract is concluded.

\subsection{The interest rate and the return rate of Musharakah, the impact on investment}

The earnings forecast one of the main determinants of the investment decision in the conventional economics. The investors make their decisions to carry out the investment when it is profitable. The profitability of new investment depends on the expected inflow of net revenue, which calculated by the difference between the expected revenue over the productive age of the project and the expected cost, that includes the replacement cost and interest on the invested capital. The investor bears the risk consists of the operating risk and the financial risk when carrying out the investment. Therefore, he expects to get a return rate of the investment exceeds the prevailing interest rate in the banks. Accordingly, the net 
REPS

$3,3 / 4$

\section{4}

income is deducted at the rate of expected return, which represents the marginal efficiency rate of investment.

Consequently, the investor takes his decision to invest according to the following equation:

$$
\mathrm{C}_{0}=\mathrm{R}_{1} /(1+g)^{1}+\mathrm{R}_{2} /(1+g)^{2}+\ldots+\mathrm{R}_{n} / \mathrm{R}_{n} /(1+\mathrm{g})^{n}
$$

where:

$\mathrm{C}_{0}$ : fixed capital value.

$\mathrm{g}$ : Marginal efficiency rate of investment.

$\mathrm{R}$ : Expected annual net return.

This equation must be at least equal zero or a positive.

When the quantity of investment increases in the economy, the profitability of new investments tends to decline. As a result of the emergence of diminishing returns, the decrease in final goods prices, and the higher expense of replacement by growing the demand for investment. These lead to decreasing the marginal efficiency rate of capital in the economy (Dwivedi, 2010). Therefore, the demand for investment by each investor will be affected by an inverse relationship with the interest rate.

The investment function takes the following formula:

$$
\mathrm{I}=\mathrm{f}(\mathrm{r})
$$

where $r$ is the interest rate.

The interest rate in banks considers a significant determinant to investment, which included in the marginal efficiency rate of investment. It is standard for opportunity cost approaching being free of risk, as well as the interest rate is a standard for comparative returns for savings vessels which determine savings decisions. Therefore, the interest rate is the most important monetary policy variable to influencing the economic activity.

In the case of failure investor's expectations for investment returns on the actual returns, the investor bears the investment risk away from the saver. That leads the economy to lie out of the equilibrium towards the lower level of income, where the investor is reluctant to demand more funds for investment. So the Central bank cuts the interest rate to reduce the cost of financing risk, and the saver bears a lower rate of return on his savings to stimulate investment and increase the level of economic activity.

As well as determine a fixed rate on lending and borrowing creates a money market includes in part, a negative reflection on the real market, due to borrowing for speculative purposes either securities or commodities and lead to higher stock prices by more than the fair value and stock market bubbles. It also increases the funds demanded to import and consumption. The inflation rate increases and stimulates the central bank to raise interest rates again.

The marginal sufficiency rate of investment concept applies to the decisions of either net investment or replacement investment, where the depreciation allowances will be reinvested only when it adds to the company's profits (Hoover, 2012). The marginal sufficiency rate of investment compares with the interest rate; the investment decision will be taken as long as the marginal efficiency rate of investment is more than the interest rate.

Through Musharakah financing, the interest rate does not have a role in a balance between the lendable funds' supply and demand on it, thus between savings and 
investment, being replaced by return rates of Musharakah, this enables to overcome the two main disadvantages of the interest rate as an instrument of monetary policy:

- The use of interest rate in the equilibrium of the supply of lendable funds and demand on it includes lags to balancing at a high level of economic activity or a lower level. It has an impact on the performance of companies to rise or decline according to the direction of the interest rate effect on the level of economic activity. While Musharakah financing ensures all parties of the process participate in the risk and profit, saver, bank and the investor. Therefore, the savings always creates a demand on it for investment, and the economic performance level depends on the efficiency of investment management, not on the interest rate as instrument to stimulate investment or encourage savings.

- The interest rate instrument is inflexible; investor bears interest burden as a financial risk. It determines arbitrarily according to maturity for loans between the bank and depositors, and between the Bank and investors. While Musharakah financing includes replacing the interest rate by three rates of return to post more flexible and varies according to the type of project funded by Musharakah. It consists of the return rate of depositors' Musharakah (P1), the return rate of Bank's Musharakah (P2) and the return rate of investor's Musharakah (P3). It leads to more effective monetary policy instruments in the management of economic activity. Whereas, the increase in the return rate of depositor's Musharakah encourages savings and provides funds for investment, as well as the increase in the return rate of investor's Musharakah encourages investors to increase the investment, as well as reducing the return rate of bank's Musharakah increase both savings and investment.

Therefore, the investment function takes the following formula:

$$
\mathrm{I}=\mathrm{I}_{0}+\mathrm{mP}_{1}-\mathrm{mP}_{2}+\mathrm{mP}_{3}
$$

The investment is positively related to the return rate of depositor's Musharakah and the return rate of investor's Musharakah, whereas it is an inverse relationship with the Bank's Musharakah.

Zakat contributes to ensuring the continuation of the positive impact of the Musharakah financing in influencing the economic activity. Whereas, the individuals will not keep their money idle due to the shrinking by zakat. Also, the desire to reserve the funds for speculation diminishes because they will get negative return rate equivalent the rate of zakat.

\subsection{The present value and the return rate of Musharakah}

The concept of present value is significantly related to savings, while, the concept of marginal sufficiency rate of investment related to investment. Banks are using the present value when they give the loans to offset the decline in the money value over time, also, when getting a profit for risks assumed by both general risks such as inflation or private risks such as tripping. The savers get their savings in the subsequent periods, so they wish to gain a return on their savings more than the lower in purchasing power of savings; therefore, they compare the interest rate and the inflation rate to earn positive real interest rate.

The present value concerns the decline in the value of money due to the time agent, without including the effect of other economic factors such as recession or inflation on the

Impact of
Musharakah
financing 
REPS

$3,3 / 4$

money value. Therefore, when using Musharakah financing, the present value calculation can be replaced the inflation rate rather than the interest rate, where the savers rely on the real value of money. The central bank will target the inflation and reduces the range of fluctuating as little as possible, which leads to the stability of the economy and stimulates the investment.

Also, the use of inflation rate as a discount rate instead of the interest rate overcomes a significant problem when determining the internal rate of return for the project. Whereas, if the price level increases over time at a higher rate than the return rare of the project, the real return will be less than its present value in terms of the interest rate, and the project has become a loser. Therefore, the present value depends on the inflation rate considers more reliability in expressing the profitability of the project from the economic perspective.

Accordingly, the present value takes the following formula:

$$
\mathrm{PV}=\frac{\mathrm{R} 1}{(1+\mathrm{i})}+\frac{\mathrm{R} 2}{(1+\mathrm{i}) 2}+\ldots \ldots \ldots \ldots \ldots+\frac{\mathrm{Rn}}{(1+\mathrm{i}) \mathrm{n}}
$$

where $i$ is the inflation rate.

In the case of Musharakah financing and use, the inflation rate as an instrument for the discount of the return of projects, loans and bills, the Central bank's control of determining the legal reserve ratio and the amount of commercial banks reserves will be reduced for the influence of the participants' preference, where the amount of reserves at the commercial bank depends on the preference of individuals to participate through the commercial bank or demand of money as a currency, as well as the performance of the Central bank.

Therefore, when individuals would save at the commercial bank by Musharakah, while the total stock of currency is relatively stable, they have an impact on reserves due to their preference. The Central bank can overcome this influence by change the volume of money supply. The Central Bank has more effect of the banks' reserves.

Also, the bank, depositors, and investors bear the cost of keeping reserves, which rise when the rate of inflation as a discount rate decreases and the return on managed assets increases. So, besides the Central bank authority, the influence of preferences of the bank, savers and investors on the quantity of the money supply will increase to make the money supply more flexible to the changes in the inflation rate as a discount rate. Therefore, the Central bank regulates the Musharakah rates between the bank and investor on the one hand, and between the bank and depositor, on the other hand, to affect the rates of return, the amount of the commercial bank reserves and money supply.

\subsection{Marginal sufficiency rate of investment and the return rate of investor's Musharakah}

Keynes used the concept of marginal efficiency of capital to express the additions to the return on the total capital, which deducted by the rate of expected return over the project age for equal the cost of initial investment.

Therefore, the marginal sufficiency rate of investment represents a required rate of return on investment includes operational risk which involves uncertainty, and financial risk. In the case of Musharakah financing, the financial risk which represents the risk of default would not exist. Also, the rate of free risk can be replaced with the equivalent of purchasing power decline. Therefore, the marginal efficiency rate of investment comprises the inflation compensate, operating compensate and zakat compensate:

$$
\mathrm{g}=\mathrm{i}+\mathrm{O}+\mathrm{z}
$$


where:

$g$ : Marginal efficiency rate of investment.

$i$ : Inflation compensate.

$o:$ Operational compensate.

$z$ : Zakat compensate.

\section{Impact of Musharakah financing}

The investor's return determines according to the Musharakah rate between the bank and the investor, and the success of the project and earnings depend on the efficiency of operational risk management by the investor. Therefore, the bank can increase the return for the investor by increasing the investor's Musharakah (P3), in return decrease the Bank's Musharakah (P2). Therefore, both the return rate of Bank's Musharakah (P2) and the return rate of depositor's Musharakah can be seen as a residual of the return rate of investor's Musharakah (p3).

$$
\mathrm{U}=\mathrm{P}-\mathrm{P} 3
$$

where $\mathrm{P}$ : the total return.

$$
\mathrm{U}=\mathrm{P} 1+\mathrm{P} 2
$$

Hence:

$$
\begin{aligned}
& \mathrm{P} 1+\mathrm{P} 2=\mathrm{P}-\mathrm{P} 3 \\
& \mathrm{P}_{3}=\mathrm{P}-\left(\mathrm{P}_{1}+\mathrm{P}_{2}\right)
\end{aligned}
$$

The residual return $(\mathrm{U})$ divides between the bank and depositor according to the return rate of depositor's participation (P1) and the return rate of bank's participation (P2).

Therefore, the marginal sufficiency rate of investment as the following, assuming the revenues are regular:

$$
C=\frac{R}{1+g}
$$

where:

C: replacement cost of the new capital.

$$
\begin{gathered}
(1+g) \times C=R \\
C+C g=R \\
C g=R-C \\
g=\frac{R-C}{C}
\end{gathered}
$$


In terms of the investor:

$3,3 / 4$

$$
\begin{aligned}
& \mathrm{g}=\frac{\mathrm{R}(\mathrm{P}-\mathrm{P} 2)-\mathrm{Cp} 3}{\mathrm{Cp} 3} \\
& \mathrm{~g}=\frac{\mathrm{RP}-\mathrm{RP} 2-\mathrm{Cp} 3}{\mathrm{Cp} 3}
\end{aligned}
$$

If the revenues are irregular, the marginal sufficiency rate of investment as the following:

$$
\mathrm{C}=\frac{\mathrm{R} 1}{(1+\mathrm{g})}+\frac{\mathrm{R} 2}{(1+\mathrm{g}) 2}+\ldots \ldots \ldots \ldots \ldots+\frac{\mathrm{Rn}}{(1+\mathrm{g}) \mathrm{n}} .
$$

where g: marginal efficiency rate of investment.

When the total revenue increases the marginal sufficiency rate of investment increases, as well as when the return rate of investor's Musharakah rises, the marginal sufficiency rate of investment increases.

Therefore, the monetary policy can use the return rate of investor's Musharakah in influencing the level of economic activity. In the case of a recession, the Central bank can increase the ratio of investor's Musharakah which raises the Musharakah return of the organizer and increases the level of the marginal sufficiency rate of investment, consequently, the quantity of investment.

Therefore, the Central bank can overcome the recession by the integration of the money market instruments and the real market without lags, which causes a slow response in economic activity as the conventional economy.

Also, in the case of the high economic activity that about to turns into inflation, the Central bank can shrink the ratio of investor's Musharakah, which leads to decrease the investors' return, as well as the marginal efficiency rate of investment. That causes the reducing in the private investment expenditure and the economic activity.

2.6 Monetary policy and the return rate of depositors' Musharakah and bank's Musharakah The liquidity preference affected by zakat; which represents the cost of preserving liquid money. It stimulates the exploitation of monetary stocks in the types of economic activity that relatively generate higher revenues than zakat rate, inflation rate, and the risk rate, so it contributes to the efficient allocation of economic resources and raises the economic activities.

Therefore, the individuals wouldn't leave their monetary stocks idle, where zakat and inflation will devaluate it; they have three options to dispose of their money:

(1) invest their money in financial assets such as stocks and sukuk;

(2) spending their money on fixed assets and real estate to compensate the decline of purchasing power of money and avoid bearing zakat; and

(3) deposit their money in banks to gain the Musharakah rate. 
In the case of the third option, the depositors must earn a return according to the following formula:

$$
\frac{\mathrm{Rp} 1}{\mathrm{~S}} \geq \mathrm{Rz}+\mathrm{Ri}+\mathrm{RP}_{1}
$$

Impact of Musharakah financing

where S: The value of assets invested by depositors.

$$
\begin{gathered}
\mathrm{RP}_{1} \geq \mathrm{RSz}+\mathrm{RSi}+\mathrm{RSP}_{1} \\
\mathrm{RP}_{1}-\mathrm{RSz}-\mathrm{RSi} \geq \mathrm{RSP}_{1} \\
\left(\mathrm{P}_{1}-\mathrm{z}-\mathrm{Si}\right) \geq \mathrm{SP}_{1}
\end{gathered}
$$

The equation becomes accepted by the depositors and the bank at the low level as follows:

$$
\left(\mathrm{P}_{1}-\mathrm{Z}-\mathrm{Si}\right)=\mathrm{SP}_{1}
$$

The increase in the returns of depositors' Musharakah raises available funds for investment. Also, the increase in the inflation rate leads to decrease deposits for investment. As well as, zakat reduces available funds for reinvestment by percentage of zakat. Therefore, the Central bank can attract a financial surplus of individuals and institutions to increase the investment by raising the depositor's participation $(P 1)$ and reduce the Bank's participation $(P 2)$. This causes the increase in the rate of depositors' Musharakah and decreases the rate of banks' Musharakah. Consequently, encourage the depositors to arise their savings by Musharakah.

\section{Conclusion}

The discount rate is an essential Instrument for monetary policy in influencing the amount of credit granted by banks in the conventional economy, whether for short-term by dealing with the commercial papers or long-term through rediscount rate. It has significant criteria to determine the interest rate, which is the primary monetary variable affects the economic activity through influencing funds supply for savings, as well as borrowing for investment. The use of the return rate of Musharakah is more efficient and flexible implement to affect the economic activity in the Islamic economy; it includes three rates of return; the return rate of depositors' Musharakah, the return rate of Bank's Musharakah, and the return rate of investors' Musharakah. They can be used to achieve the equilibrium in the money market and the real market simultaneously without lags as in the conventional economy.

The use of the inflation rate as an instrument for discounting the projects return, loans and bills in Musharakah financing reduces the Central bank controls of determining the legal reserve ratio and the reserves of commercial banks due to the influence of the participant's preference. The Central bank can overcome this influence by changing the volume of money supply.

The Central bank determines the return rates of Musharakah, between the bank and investors on the one hand, and between the bank and depositors, on the other hand, to affect the reserves of commercial banks, the money supply and the economic activity.

In the case of the economic boom, that about to turns into inflation and the funds demanded to the investment increase. The Central bank reduces the ratio of investor's Musharakah, which causes the decrease on the investor's return and the marginal efficiency 
REPS

$3,3 / 4$

rate of investment. Therefore, the funds demanded to the investment decrease. In return, the Musharakah ratio of the depositor and the bank increases. So, the savings and liquidity arise at banks causes the lower on the economic activity.

In the case of a liquidity crisis, that about to turns into recession and the funds demanded to the investment decrease. The Central bank can provide funding for the banks by reducing the ratio of banks' Musharakah and increase the depositors' Musharakah, which increases the savings at the bank to provide liquidity or participate in more profitable projects. Also, the Central bank raises the investor's Musharakah to spur the funds demanded to investment.

The Central bank can influence the structure of economic activity, as well as the allocation efficiency of resources by using the return rate of Musharakah. If the allocation of resources for public sector less efficient, the Central bank can reduce Musharakah ratio of the bank and raises Musharakah ratios for both depositors and investors. This lead to increasing the money supply for savings and increasing the funds demanded to investment, as well as increase the growth rate of the private sector. Vice versa, if the allocation of resources for the public sector more efficient, the Central Bank can increase the Musharakah ratio of the bank and reduce the Musharakah ratios of depositors and investors. That raises available funds of the banking system and the provision of liquidity, to finance the public sector, through the public sector Musharakah.

Zakat has a positive impact on Musharakah financing, as well as in influencing the economic activity. Whereas, it prevents the retention of money idle due to the contraction by zakat. Also, it reduces the money for speculation, which gets a negative return rate equivalent the rate of zakat.

\section{References}

Abdullah, A. and Saiti, B. (2016), "A Re-examination of musharakah bonds and waqf development: The Case of Singapore", Intellectual Discourse, pp. 541-562, available at: ///C:/Users/Hatm/ Downloads/933-1-2076-1-10-20170106.pdf (accessed 16 September 2017).

Ahmed, G.A. (2008), "The implication of using profit and loss sharing modes of finance in the banking system, with a particular reference to equity participation (partnership) method in Sudan", Humanomics, Vol. 24 No. 3, p. 184, available at: www.emeraldinsight.com/doi/abs/10.1108/ 08288660810899359 (accessed 21 April 2017).

Ahroum, R. and Achchab, B. (2017), "Pricing of Sukuk Musharakah with joint venture as underlying, beyond the use of PLS ratio", Journal of Islamic Accounting and Business Research; Bingley, Vol. 8 No. 4, pp. 406-419, available at: www.emeraldinsight.com/doi/pdfplus/10.1108/JIABR-032016-0036 (accessed 22 November 2017).

Ariffin, N.M., Kassim, S. and Razan, D.A. (2015), "Exploring application of euity-based financing through Musharakah Mutanaqisah in Islamic Banks in Malaysia: perspective from the industry players", International Journal of Economics, Management and Accounting, Vol. 23 No. 2, pp. 241-261, available at: http://journals.iium.edu.my/enmjournal/index.php/enmj/article/view/ 338 (accessed 9 October 2017).

Bank Negara Malaysia (2007), "Annual Banking Statistics”.

Bank Negara Malaysia (2010), Shariah Resolutions in Islamic Finance, 2nd ed., pp. 40-41.

Bank Negara Malaysia (2015), “Islamic Financial Service Industry Stability Report 2015”, pp. 7-8.

Bank Negara Malaysia (2018), "Monthly Statistical Bulletin”, Varies Issues.

Bosca, L.C. (2015), "Criticism of Conventional Economy and of the homo economicus paradigm in the philosophy of Islamic Economy", The Academy of Economic Studies, Bucharest, Vol. VII No. 1, pp. 77-89, available at: www.ceeol.com/search/article-detail?id=291168 (aceesed 4 January 2017). 
Chong, B.S. and Liu, M. (2009), "Islamic banking: Interest-free or interest-based?", Pacific-Basin Finance Journal, Vol. 17 No. 1, pp. 125-144, available at: ///C:/Users/Hatm/Downloads/1-s2.0-S0927 538X08000036-main.pdf (accessed 24 February 2017).

Chong, B.S. and Liu, M. (2009), "Islamic banking: interest-free or interest-based?, Op. Cit.", pp. 125-144, available at: ///C:/Users/Hatm/Downloads/1-s2.0-S0927538X08000036-main\%20(1).pdf (accessed 30 March 2017).

Dwivedi, D.N. (2010), Macroeconomics, 3rd ed., McGraw-Hill Education, Chicago, 3rd Edition, pp. 177-179.

Ernst and Young (2016), World Islamic Banking Competitiveness Report 2016, London, pp. 10-11, available at: www.scribd.com/document/350212828/ey-world-islamic-banking-competitivenessreport-2016-pdf (accessed 8 April 2017).

Hasan, Z. (2016), "How Islamic is the Diminishing Musharkah Model used for Home Financing?", Turkish Economic Review, Vol. 3 No. 3, pp. 443-452, available at: www.kspjournals.org (accessed 3 December 2017)

Hassan, M K., Smolo, E. (2011), "The potentials of musharakah mutanaqisah for Islamic housing finance", International Journal of Islamic and Middle Eastern Finance and Management, Vol. 4 No. 3, pp. 237-258, available at: www.emeraldinsight.com/1753-8394.htm (accessed 30 September 2017).

Hassan, M.K. and Soumare, I. (2015), "Guarantees and Profit-Sharing Contracts in Project Financing", Journal of Business Ethics, Vol. 130 No. 1, pp. 231-249, available at: https://link.springer.com/ article/10.1007/s10551-014-2201-0 (accessed 22 September 2017).

Hoover, K.D. (2012). Applied Intermediate Macroeconomics, 1st ed., Cambridge University Press, New York, pp. 558-562.

Iqbal, Z. (1997), "Islamic financial systems", Finance \& Development, IFM, Essen, pp. 42-45, available at: www.imf.org/external/pubs/ft/fandd/1997/06/pdf/iqbal.pdf (accessed 22 February 2017).

Kashi, A. and Mohamad, A. (2017), "Does Musharakah Mutanaqisah converge with Bai Bithamin Ajil and conventional loans?" International Journal of Law and Management, Patrington, Vol. 59 No. 5, pp. 740-755, available at: www.emeraldinsight.com/doi/abs/10.1108/IJLMA-04-2016-0044. (acessed 7 September 2017).

Khan, M.M. and Bhatti, M.I. (2008), "Islamic banking and finance: on its way to globalization", Managerial Finance, Vol. 34 No. 10, pp. 709-710, available at: www. emeraldinsight.com/doi/ pdfplus/10.1108/03074350810891029 (accessed 4 April 2017).

Khatat, M.E. (2016), "Monetary Policy in the Presence of Islamic banking”, Working Paper, IMF, Vol. 16 No. 72, pp. 1-40, available at: www.imf.org/external/pubs/ft/wp/2016/wp1672.pdf (accessed 3 November 2017).

Malik, A., Malik M.S. and Shah, H. (2011), "an Analysis of Islamic Banking and Finance in West: From Lagging to Leading”, Asian Social Science, Vol. 7 No. 1, pp. 179 -185, available at: ///C:/Users/ Hatm/Downloads/8905-27237-1-PB.pdf (accessed 24 March 2017).

Mikail, S.A. and Rani, M.S.M. (2016), "Shari'ah Contracts Underpinning Musharakah Mutanaqisah Financing: A Conceptual analysis", International Journal of Islamic Finance, Vol. 8 No. 1, pp. 35-66, available at: https://search.proquest.com/openview/35fb886896747dabec7c6b7526437d77/1?pqorigsite $=$ gscholar\&cbl=2031957) (accessed 31 October 2017).

Ouidad, Y. (2013), "Does Profit Loss Sharing (PLS) solve moral hazard problems?", Journal of Islamic Economics, Banking and Finance, Vol. 9 No. 3, available at: http://ibtra.com/pdf/journal/ v9_n3_article1.pdf (accessed 21 October 2017).

Ramic, S. (2012), "Participation banking in european context", Journal of Economic and Social Studies, Vol. 2 No. 1, pp. 91-110, available at: https://search. proquest.com/docview/1400625262/ fulltextPDF/9CC9E81E5DEE4102PQ/9?accountid=145382 (accessed 12 November 2017).

Saad, N.M. and Abdul R.D. (2013), "Towards an Application of Musharakah Mutanaqisah Principle in Islamic microfinance", International Journal of Business and Society, Vol. 14 No. 2, pp. 221-234, 
REPS

$3,3 / 4$ available at: www.ijbs.unimas.my/repository/pdf/Vol14No2paper4.pdf (accessed 25 October 2017).

Sayim, F. (2015), "The Participation Banking as A Distinctive Method and The Its Growing in the Turkish Finance Market - Period: 2007-2013”, Emerging Markets Journal, Vol. 5 No. 1, pp. 92-111, available at: ///C:/Users/Hatm/Downloads/73-530-1-PB\%20(1).pdf (accessed 14 March 2017).

Selim, H.T. (2008), “An Islamic Capital Asset Pricing Model”, Emerald Publishing Limited, Vol. 24 No. 2. pp. 122-129, available at: www.emeraldinsight.com/doi/abs/10.1108/08288660810876831 (accessed 30 November 2017).

Tahir, S. (2013), "Fiscal and Monetary Policies in Islamic Economics: Contours of an Institutional Framework", Islamic Economic Studies, Vol. 21 No. 2, pp. 1-22, available at: www.irti.org/ English/Research/Documents/IES/016.pdf (accessed 12 October 2017).

Tahmina, T.N. (2013). "The Barriers to, and Incidence of, Islamic Banking and Finance in Canada", Telfer School of Management, University of Ottawa, pp. 1-49, available at: https://ruor. uottawaca/bitstream/10393/26246/1/Tahmina_Tanita_2013_Thesis.pdf (accessed 21 March 2017).

\section{Corresponding author}

Hatem Adela can be contacted at: hatem.adileh@aue.ae

For instructions on how to order reprints of this article, please visit our website: 